\title{
Acting the Act in The Changeling
}

\author{
Lisa Hopkins \\ Sheffield Hallam University
}

\begin{abstract}
This paper focuses on the dumb-show which opens Act IV of Middleton and Rowley's The Changeling. Using evidence from other Renaissance drama and from within the play itself for the use of the word "act" to describe the interval between the acts, the paper argues that the dumb-show ostensibly offers one kind of act but in fact serves as a metaphoric representation of another, unactable "act," the sex act between BeatriceJoanna and De Flores. It further suggests that the events of the dumb-show serve as an encapsulation in miniature of many of the concerns of the play as a whole-wonder, absence, seeming, and the hierarchies of class and gender.
\end{abstract}

At the beginning of act IV of The Changeling Middleton has recourse to the curiously oldfashioned device of the dumb-show (Gurr 174). The assembled cast mime the flight of Piracquo, the wedding of Beatrice and Alsemero, and the appearance of Alonzo's ghost to De Flores, before clearing the stage for a soliloquy by Beatrice-Joanna. Dumb-show is often a means of hastening a narrative that would take too long to dramatise, and that may perhaps be the case here, though the amount of time devoted (quite unnecessarily, in the minds of many critics [Daalder XIX]) to recounting the asylum sub-plot suggests that Middleton and Rowley were not overburdened with material to fit into their five acts. What further militates against a shortness-of-time theory is the fact that the dumb-show is immediately followed by a fifty-one line soliloquy from Beatrice-Joanna, and though this is certainly of enormous importance both psychologically and in terms of the plot, its relatively leisurely pace certainly forms a striking contrast with what has gone before. I propose to suggest that the dumb-show is included by Middleton not so much for reasons of economy but because it offers a particularly potent symbol for conveying to the audience a set of acts and issues which he would otherwise be utterly unable to present on the stage.

Immediately before the dumb-show, at the end of III.4, Beatrice-Joanna is led off the stage by De Flores to yield him her virginity in payment for his murder of her fiance, 
Alonzo de Piracquo. When De Flores had originally agreed to commit the murder, Beatrice had no idea that this was to be his intended reward; discovering it, she is horrified, but knows that she has no choice but to agree once De Flores has threatened her with the exposure of the murder. The final lines of the scene contain a comment by De Flores both on her evident distress, and on his own conviction that it is needless:

'Las, how the turtle pants! Thou'lt love anon

What thou so fear'st and faint'st to venture on. (III.4.169-70)

Beatrice's changing behaviour during the remainder of the play certainly seems to suggest that De Flores may be right in this assumption. The next time we see her is only a few moments later in stage time, but the loss of her virginity which we must believe to have taken place seems already to have affected her. Previously reliant on De Flores for the performance of villainy, she seems to have acquired a new resolution and independence, as she single-handedly raids her husband's closet and suborns Diaphanta for the bed-trick; and soon her growth of affection for De Flores confirms the audience's sense that she has been fundamentally altered by her experiences (Callaghan 62). She is indeed, as De Flores calls her, "the deed's creature" (III.4.137).

The deed itself, however, is one which fundamentally defies stage representation (McLuskie 116). Quite apart from the fact that Beatrice-Joanna is being played by a boy actor, on-stage sex is out of the question for the Jacobean theatre, so that instead of the act of darkness, we see the dumb-show. The extent to which the one substitutes for the other is interestingly underlined by the fact that the very word "act" is equally applicable to both. The supposed defloration takes place during the change of acts, and the music which habitually punctutates act divisions at indoor theatres (The Changeling was first performed at the Phoenix [Daalder XXXV]) was often termed the act, as in the stage direction which opens act II of John Marston's The Malcontent: "whilst the act is playing, enter unbraced, two pages" (Hunter II.1.s.d.). Indeed the point has been made earlier in The Changeling itself, in the suggestive stage direction which opens III.1: "In the act-time De Flores hides a naked rapier." Thus, in an ingenious pun, one sort of act deputises for another, unactable act.

Equally, however, the matter of the dumb-show forms a suitable metaphoric representation of the unstageable act of Beatrice's deflowering. Vermandero's opening "action of wonderment at the flight of Piracquo" points us clearly in the direction of two key areas of concern which the play repeatedly highlights: astonishment and absence. The very setting of the sub-plot in a lunatic asylum recalls the fact that in Jacobean society an asylum forms a spectacle, a locus of wonderment, a suitably authorised direction for the roving, curious gaze. In Alicante, however, the official sites of wonderment-temple, asylum and fort-have failed to fix the wandering eye, which therefore initiates in the majority of characters a state of virtually ceaseless change. But what the eye sees, it also fundamentally misapprehends, for few things in Alicante are what they seem to be: "quick" Diaphanta is a true maid (IV.1.91); lunatics are courtiers; Beatrice is a whore. As Vermandero so prophetically cautions Alonzo, 
our citadels

Are placed conspicuous to outward view

On promonts' tops, but within are secrets. (I.4.161-3)

Moreover, the penetration of that secret entails death for Alonzo: the moment of apparent fruition culminates in loss of all.

Absence is similarly figured in the text in the intense negativity which characterises all the principal characters' goals. Beatrice wants always the man she has not; Alibius (always already absent, elsewhere) and Alsemero both desire chiefly abstinence in their wives; Antonio's love is exposed as empty as he misperceives the object of his love at the very moment that he has apparently attained it. Inability to attain goals shadows the text like the memory of Beatrice-Joanna's dead sister, the double who exists only in imagination. Finally, the play dramatises a satisfaction which can be obtained only through purgation: a childless, marriageless future awaits those characters who survive.

It is of course also the twin poles of astonishment and absence which fundamentally structure Beatrice's experience of the unactable act of sex. Surprised by her own change in feelings towards De Flores, she is nevertheless aware that the knowledge afforded her by the carnal act of knowing is, in her society, unacknowledgeable, since intercourse has taken place outside the licensed bonds of matrimony. From now on, Beatrice must be defined increasingly as a series of negatives: not-virgin, not-wife, finally not-alive, and (unlike her dead sister) not even remembered, as Alsemero entreats his father-in-law, "Let it be blotted out" (V.3.182). Anything that she may have become, instead of the roles afforded her in Alicante which she so conspicuously fails to fulfil, is doomed to an utter lack of recognition: only its absent potential can be figured in the text, marked in the way that Beatrice continues to fascinate both students and producers to a degree that seems strangely out of proportion with any actual attractions of her character.

The rest of the dumb-show proves equally pithy. Having wondered "at the flight of Piracquo" (itself, of course, an absence on the stage, since it is a concept rather than an action and thus impossible to represent directly), Vermandero then goes on to point at Alsemero, indicating him as his new son-in-law, "the gentlemen seeming to applaud the choice." The fact that they merely "seem" to do so is, on one level, dictated by the conditions of the dumb-show itself, and does little more than acknowledge the potential ambiguity in the interpretation of any physical gesture; nevertheless, even in this sense it is interesting, since its direct implication is that without a verbal gloss all action is susceptible of being taken to stand for that which it is not-a precise analogy to my. argument that the dumb-show itself is to be seen as a substitute representation of the unstageable act of sex. On another level, moreover, the uncertainty surrounding the gentlemen's responses surely picks up on the general atmosphere of deceit, secretiveness and spying which pervades Alicante, manifesting itself in the literal or metaphorical disguise of so many of the principal characters. Finally, we need to remember that what we are shown here also involves a complex sequence of power relations. Vermandero's gentlemen are dependent on him, as is shown by his clear ability to discipline both Antonio and Francisco when their deceptions are discovered; however, he apparently feels the need to seek at least their nominal approval as he disposes of his daughter in marriage. 
The verb "seem" may perhaps serve to prise apart some of the heavily-charged ambiguities which punctuate this particular spectacle of power. Does Vermandero genuinely require their assent? Do they genuinely give it? And what relation does such stage-managed agreement bear to the deed for which all this is, as I argue, a metaphorical representation: the deflowering of Beatrice, to which she too has given an enforced consent which would leave the precise legal status of the act hovering uneasily between rape, seduction and consensual sex, in a way which lays unusually bare the politics of power which, in so unequal a society, structure all sex acts.

Sexual politics also, of course, inform the next action of the dumb-show: "[Exeunt in procession VERMANDERO], ALSEMERO, JASPERINO and GENTLEMEN. [Enter] BEATRICE, the bride, following in great state, accompanied with DIAPHANTA, ISABELLA, and other GENTLEWOMEN." Walking not side by side, as in traditional images of the marriage ceremony, but separately and in a clear visual assertion of the hierarchy whereby the male dominates over the female, Alsemero and Beatrice offer a striking image of the disharmony which characterises not only their own marriage but all the male-female interactions which we see in the play. One of the hardest aspects of the tragedy for modern students to accept often proves to be the pitiful state of Isabella's marriage, coupled with the fact that we are apparently supposed to be pleased that at the end of the play her only reward for her absolute obedience to the gender codes of her society will be that her loveless marriage is palliated by a little more freedom of movement. The presence of Isabella in this scene-the first time that plot and sub-plot have come so materially together - forcibly reminds us of the probable destiny of "the bride," a suggestion that will be powerfully reinforced a few lines later when Beatrice discovers that she is married to a man who has been careful to include a portable virginity-testing kit in his travelling bags. The "great state" of Beatrice on this occasion can be read as an ironic counterpart to the small esteem in which women in Alicante are held in the normal run of things. Moreover, this formal celebration of the marriage sits in sharp tension with the secret reality of consummation which it figures.

The final event of the dumb-show is even more sharply and obviously related to the dark and hideous deed which this more public action displaces: "[Enter] DE FLORES after all, smiling at the accident. ALONZO'S ghost appears to DE FLORES in the midst of his smile; startles him, showing him the hand whose finger he had cut off. They pass over in great solemnity." The "great solemnity" suffers a radical visual disturbance in the eyes of the ironically aware audience by this sudden, startling appearance of the ghost. Authorised in contemporary drama as a standard signifier of the legitimacy of the patriarchal law which underwrites both the rule of the father on earth and ths divine power in heaven, this ghost differs oddly from many of his predecessors both in the brevity of his appearance and also in the nature of his message. Alonzo's four-fingered gesture (it is, presumably, the wedding ring finger that is missing) encapsulates both the absences and the presences which characterise this ill-fated marriage. Lacking the most fundamental of all signifiers of marriage - the ring-his mutilated hand equally suggests the lack of that which ultimately authorises marriage, the phallus. This is obviously only too applicable to Beatrice-Joanna's marriage, which lacks love (the ring-finger was popularly believed to be joined by a vein directly to the heart) and will also remain unconsummated, Alsemero 
being deluded by the presence in his bed of Diaphanta. Moreover, hers is only one of many unwanted presences which will deform this marriage, the most crucial being obviously that of De Flores himself. Relegated by low social rank to being last in the procession, he is ironically forced into a position where he will command the maximum of audience attention, since he is both isolated and also provides the formal culmination of the dumbshow. The ghost's gesture to him may well be seen as bearing a clear relation to the habitual sign for cuckoldry; and as such, it points literally and metaphorically both to his pre-nuptial cuckolding of Alsemero and to the added irony that the wedding of his mistress should in logic lead directly to his own sexual betrayal. His laughter is, therefore, doubly inappropriate at such a time.

The act which cannot be acted is, therefore, figured at a multiplicity of levels in the dumb-show which structurally displaces it: welling to the surface, the hidden deed will in fact have a variety of repercussions. Principally, these will be for Beatrice-Joanna, the figure who, as "the bride," is the most profoundly misinterpreted and misperceived in the dumb-show. For her, the act must be so completely erased from the visible fabric of her life that, from now on, everything she does must be an act in another sense: she must live a lie, acting out one role to conceal the act of darkness which has changed her true life into something quite different. It is perhaps appropriate that this should be dramatised by that most obviously theatrical and acted of all types of stage representation, the dumb-show.

\section{Works Cited}

Callaghan, Dympna. Woman and Gender in Renaissance Tragedy. Hemel Hempstead: Harvester Wheatsheaf, 1989.

Daalder, Joost, ed. The Changeling. London: Black, 1990.

Gurr, Andrew. The Shakespearean Stage, 1575-1642. 2nd ed. Cambridge: Cambridge UP, 1980. Hunter, George, ed. The Malcontent. Manchester: Manchester UP, 1975.

McLuskie, Kathleen. "Lawless Desires Well Tempered." Erotic Politics: Desire on the Renaissance Stage. Ed. Susan Zimmerman. London: Routledge, 1992. 103-26. 